\title{
Large mammal fauna of the West Siberian forest-tundra zone in the Late Holocene
}

\author{
Olga P. Bachura*, Pavel A. Kosintsev \& Tatyana V. Lobanova \\ Olga P. Bachura [olga@ipae.uran.ru], PavelA. Kosintsev [kpa@ipae.uran.ru],TatyanaV.Lobanova [lota_64@mail. \\ ru], Institute of Plant and Animal Ecology, Ural Branch of the Russian Academy of Sciences, 8 Marta str. 202, Yekat- \\ erinburg 620144, Russia
}

\begin{abstract}
Changes in the Late Holocene species composition and dynamics of number of large mammal fauna are described for the forest-tundra zone of the West Siberia. The review is based on ${ }^{14} \mathrm{C}$ dated materials from cave and archeological sites. During the studied period the species composition of large mammals was nearly constant and similar to the modern one with azonal species dominating in the fauna. The faunal composition of the southern part of forest-tundra zone differed from the northern part by the presence of the beaver and otter. Minor changes in the faunal composition took place only in the northern part of this area at the end of the Subatlantic period and concerned changes in the northern boundary of the sable range. It was controlled by the shift of northern forest boundary and the increased human activities. People completely exterminated beavers and sables in the region by the mid 18th century. The mountain hare, polar fox, and reindeer had persistently high numbers during the Late Holocene in the forest-tundra zone. The numbers of other species were low. The modern mammal species composition of the forest-tundra zone was formed by the interplay of climatic change and commercial activity of people.

How to cite this article: Bachura O.P., Kosintsev P.A. Lobanova T.V. 2019. Large mammal fauna of the West Siberian forest-tundra zone in the late Holocene // Russian J. Theriol. Vol.18. No.1. P.43-50. doi: 10.15298/ rusjtheriol.18.1.05.
\end{abstract}

KEY WORDS: fauna, mammals, West Siberia, Holocene.

\section{Фауна крупных млекопитающих лесотундровой зоны Западной Сибири в позднем голоцене}

\author{
О.П. Бачура, П.А. Косинцев, Т.В. Лобанова
}

\begin{abstract}
РЕЗЮМЕ. На основании датированных материалов из местонахождений в карстовых полостях и из археологических памятников описаны изменения видового состава и динамика численности фауны крупных млекопитающих в лесотундровой зоне Западной Сибири в течение позднего голоцена. Показано, что на протяжении этого периода видовой состав крупных млекопитающих лесотундры региона был практически постоянным и сходным с современным. В составе фауны преобладали азональные виды. Видовой состав южной части лесотундры отличался от северной части наличием бобра и выдры. Небольшие изменения в фауне произошли в северной части в конце субатлантического периода и касались изменения северной границы ареала соболя. Это было обусловлено смещением северной границы леса и увеличением промысловой деятельности человека. К середине XVIII века в регионе человеком были полностью истреблены бобр и соболь. На протяжении второй половины голоцена в лесотундровой зоне Западной Сибири стабильно высокую численность имели заяц-беляк, песец и северный олень. Численность остальных видов во второй половине голоцена оставалась низкой. Современный видовой состав млекопитающих лесотундровой зоны сформировался под влиянием двух факторов: изменения климата и хозяйственной деятельности человека.
\end{abstract}

КЛЮЧЕВЫЕ СЛОВА: фауна, млекопитающие, Западная Сибирь, голоцен.

\section{Introduction}

The replacement of the Late Pleistocene periglacial landscapes into modern zonality was caused by major climatic changes of the Holocene (Velichko et al., 1994). This affected the mammalian fauna. In this context, the

* Corresponding author. bipartite forest-tundra zone is of special interest. The boundaries of both tundra and forest are strongly controlled by environmental factors. The changes in boundaries of the tundra and taiga zones inevitably affected the composition and structure of the fauna of this territory.

There is a large amount of data from the karst cavities and archeological sites pertaining to the large mammals of the West Siberian forest-tundra zone. The Late Ho- 
locene large mammals were earlier described using the data from a number of archeological sites (Kosintsev \& Lobanova, 2003, 2006). The data from cave sites were used for characterization of the large mammals at the end of the Middle Holocene (Ponomarev, 2001; Kosintsev, 2009). The small mammals from the forest-tundra zone were also described (Golovachev \& Smirnov, 2009). The data from some new the Late Holocene archeological sites (Vizgalov et al., 2013; Bachura et al., 2017; Nomokonova et al., 2017) and from cave sites have recently been obtained. This enables us to characterize the fauna of this period with considerably higher accuracy. New radiocarbon dates obtained for several sites enable a better chronology of the faunal changes. The mammalian fauna of the forest-tundra zone of the West Siberia is currently well studied. The aim of this paper is to determine the period when modern fauna of the large mammals from the West Siberian forest-tundra zone was formed.

\section{Material and methods}

The paper covers the data pertaining to the faunas from the zoogenic deposits of four karst cavities (Zveroboy, Yangana-Pe-2, Yangana-Pe-3, Yangana-Pe-5) (Ponomarev, 2001; Kosintsev, 2009) located in the limestone Yangana Pe Range (Kadebskaya \& Kosintsev, 2012) at the eastern foothills of the Polar-Urals ridge (Fig. 1). These localities are located at the boundary between the forest-tundra and tundra zones (Fig. 1). They characterize the fauna of the forest-tundra zone at its northern limit of extension. We also used the data from the archeological sites of the indigenous peoples (Gorny Samotnyel-1, Ust'-Poluy, Zelenaya Gorka, Salekhard 1, Nadymsky gorodok, Poluysky mysovoy gorodok, Zeleny Yar) and Russian settlements (Mangazeya, Obdorsk) (Fig. 1) (Vizgalov et al., 2013; Bachura et al., 2017; Nomokonova et al., 2017). All these sites are located in the central and southern parts of the forest-tundra. Zeleny Yar is the farthest southern site located at the boundary between the forest-tundra zone and the north taiga subzone of the taiga zone (Fig. 1). All collected materials are housed in the Museum of the IPAE UB RAS, Yekaterinburg.

All the materials from localities were dated by the radiocarbon or archeological methods (Tab. 1). All radiocarbon dates were calibrated in Oxcal 4.2.4 using the IntCal-13 dataset (Reimer et al. 2013). Material from layer 3 of Grotto Zveroboy according date for small mammal remains (Golovachov \& Smirnov, 2009) was attributed to the middle of the Subboreal period (SB-2). Material from layer 1 of the same locality has a very wide time interval of accumulation: 1000 - 100 years ago. Most part of this interval refers to end of the Subatlantic period (SA-3) (Tab. 1).

According to radiocarbon and archeological dates fauna can be combined into several chronological groups (Tabs. 2, 3; Fig. 2). We use the system of the Holocene chronostratigraphic units (Blytt-Sernander scheme) in modification of Khotinsky et al. (1991):

SB-1 - the beginning of the Subboreal period $3700 \mathrm{BC}$ to $2800 \mathrm{BC}$;

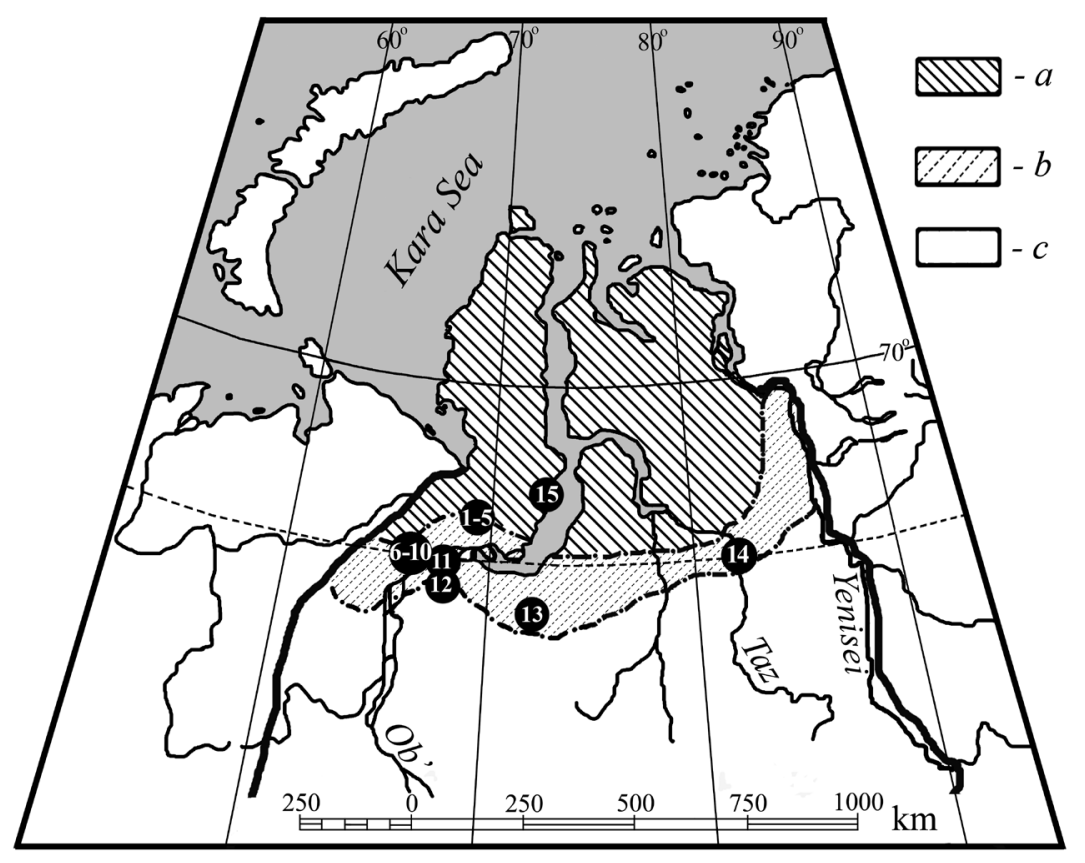

Fig. 1. Late Holocene localities of large mammals in the West Siberia. a — tundra, b - forest-tundra, c - taiga, 1 - Zveroboy, 2 - Yangana-pe-2, 3 - Yangana-pe-3, 4 - Yangana-pe-4, 5 - Yangana-pe-5, 6 - Ust'-Poluy, 7 - Salekhard-1, 8 -Zelenaya gorka, 9 - Poluysky mysovoy gorodok, 10 - Obdorsk, 11 - Gorny Samotnyel-1, 12 - Zeleny Yar, 13 — Nadymsky gorodok, 14 - Mangazeya, 15 - Bukhta Nakhodka. 
Table 1. Radiocarbon dates of the localities of the forest-tundra zone in the West Siberia

\begin{tabular}{|c|c|c|c|c|}
\hline Localities & Radiocarbon date & Calibrated age $(2 \sigma)$ & Archeological date & $\begin{array}{l}\text { Period of } \\
\text { Holocene }\end{array}$ \\
\hline Gorny Samotnyel-1 & $4370 \pm 50$, Le- 9390 & $3312 \mathrm{BC}$ to $2891 \mathrm{BC}$ & & SB-1 \\
\hline Zveroboy (layer 4) & $4100 \pm 200$, GIN-9006 & $3331 \mathrm{BC}$ to $2062 \mathrm{BC}$ & & SB-1 \\
\hline Yangana-Pe-2 (layer 3) & $3320 \pm 50$, SOAN-3930 & $1741 \mathrm{BC}$ to $1497 \mathrm{BC}$ & & SB-2 \\
\hline Yangana-Pe-3 $(-43-53 \mathrm{~cm})$ & $3640 \pm 30, \mathrm{Ua}-52353$ & $2133 \mathrm{BC}$ to $1906 \mathrm{BC}$ & & SB-2 \\
\hline Yangana-Pe-3 $(-63-73 \mathrm{~cm})$ & $3120 \pm 30$, Ua-52355 & $1451 \mathrm{BC}$ to $1291 \mathrm{BC}$ & & SB-2-3 \\
\hline Yangana-Pe-2 (layer 2) & $2380 \pm 40$, SOAN-3931 & $741 \mathrm{BC}$ to $383 \mathrm{BC}$ & & SA-1 \\
\hline Yangana-Pe-4 (layer 2) & $2095 \pm 30$, Ua-52262 & $201 \mathrm{BC}$ to $40 \mathrm{BC}$ & & SA-1 \\
\hline Yangana-Pe-4 (layer 1) & $1570 \pm 30, \mathrm{Ua}-52261$ & $414 \mathrm{AD}$ to $564 \mathrm{AD}$ & & SA-1-2 \\
\hline Ust'-Poluy & $1780 \pm 30$, Ua-47747 & $135 \mathrm{AD}$ to $333 \mathrm{AD}$ & \multirow{3}{*}{$\begin{array}{l}\text { the } 1000 \text { BC-the } 1000 \\
\text { AD }\end{array}$} & \multirow{3}{*}{ SA-1 } \\
\hline Ust'-Poluy & $1850 \pm 30, \mathrm{Ua}-47748$ & $83 \mathrm{AD}$ to $236 \mathrm{AD}$ & & \\
\hline Ust'-Poluy & $2050 \pm 30, \mathrm{Ua}-52105$ & $166 \mathrm{BC}$ to $16 \mathrm{AD}$ & & \\
\hline Salekhard-1 & & & $\begin{array}{c}\text { the } 1000 \text { BC-the } 1000 \\
\text { AD }\end{array}$ & SA-1 \\
\hline Yangana-Pe-3 $(-23-33 \mathrm{~cm})$ & $870 \pm 30$, Ua- 52352 & $1045 \mathrm{AD}$ to $1250 \mathrm{AD}$ & & SA-2 \\
\hline Yangana-Pe-5 & $840 \pm 30, \mathrm{SPb}-1341$ & $1058 \mathrm{AD}$ to $1262 \mathrm{AD}$ & & SA-2 \\
\hline Zelenaya gorka & $740 \pm 30$, Ua-52253 & $1294 \mathrm{AD}$ to $1292 \mathrm{AD}$ & \multirow{2}{*}{ 13th-14th century } & \multirow{2}{*}{ SA-2 } \\
\hline Zelenaya gorka & $640 \pm 30, \mathrm{Ua}-52254$ & $1282 \mathrm{AD}$ to $1396 \mathrm{AD}$ & & \\
\hline Zeleny Yar & & & 6th-7th century & SA-2 \\
\hline Zveroboy (layer 1) & & & 10th-19th century & SA-3 \\
\hline Yangana-Pe-3 $(-13-23 \mathrm{~cm})$ & $140 \pm 30, \mathrm{Ua}-52351$ & $1669 \mathrm{AD}$ to $1945 \mathrm{AD}$ & & SA-3 \\
\hline Nadymsky gorodok & $320 \pm 45$, SOAN-7050 & $1463 \mathrm{AD}$ to $1651 \mathrm{AD}$ & \multirow{2}{*}{$\begin{array}{l}\text { the end } 15 \text { th-the } \\
\text { beginning } 18 \text { th century }\end{array}$} & \multirow{2}{*}{ SA-3 } \\
\hline Nadymsky gorodok & $410 \pm 40$, SOAN-7048 & $1427 \mathrm{AD}$ to $1632 \mathrm{AD}$ & & \\
\hline Poluysky mysovoy gorodok & & & $\begin{array}{l}\text { the end } 16 \text { th-the } \\
\text { beginning } 18 \text { th century }\end{array}$ & SA-3 \\
\hline Mangazeya & $420 \pm 80$, IPAE- 42 & $1324 \mathrm{AD}$ to $1651 \mathrm{AD}$ & 17 th century & SA-3 \\
\hline Obdorsk & & & $\begin{array}{l}\text { the end 18th-the } \\
\text { beginning 20th century }\end{array}$ & SA-3 \\
\hline
\end{tabular}

SB-2 - the middle of the Subboreal period -2800 $\mathrm{BC}$ to $1400 \mathrm{BC}$;

SB-3 - the end of the Subboreal period - 1400 $\mathrm{BC}$ to $800 \mathrm{BC}$;

SA-1 - the beginning of the Subatlantic period $800 \mathrm{BC}$ to $300 \mathrm{AD}$;

SA-2 - the middle of the Subatlantic period - 300 $\mathrm{AD}$ to $1300 \mathrm{AD}$;

SA-3 - the end of the Subatlantic period - 1300 $\mathrm{AD}$ to $1900 \mathrm{AD}$.

We compared lists of consecutive assemblages of large mammals separately for the northern and central-southern parts forest-tundra zone. The ratio analysis of animal remains was performed for two groups. First group include ungulates: reindeer (Rangifer tarandus L., 1758) and moose (Alces alces L., 1758). Second group includes carnivores: wolf (Canis lupus L. 1758), polar fox (V. lagopus L., 1758), red fox (V. vulpes L., 1758), brown bear (Ursus arctos L., 1758), otter (Lutra lutra L. 1758), wolverine (Gulo gulo L., 1758), sable (Martes zibellina L., 1758), and weasel (Mustela erminea
L., 1758). This analysis was done also separately for different chronological periods and the northern and central-southern parts of the forest-tundra zone. Samples with only single carnivore present (Yangana-Pe-3; Yangana-Pe-5; Salekhard-1; Obdorsk) and localities of Yangana-Pe-2 and Zeleny Yar were excluded from analysis of the second group. In the Yangana-Pe- 2 all bones of the polar fox belonged to three individuals, and remains of the red fox belonged to two individuals (Kosintsev, 2009). In the Zeleny Yar all polar fox bones belonged to three individuals and all red fox bones were from one individual (Vizgalov et al., 2013). All other species are represented by single remains (Tab. 3). It is thus difficult to draw any definite conclusions on carnivorans ratios in these samples.

\section{Results}

The taphonomy of the cave and archeological sites is different. Accumulation of the bone remains in caves occurred due to the activities of the animals. Bone re- 
Table 2. Species composition and number of mammal bone remains in the localities of the northern forest-tundra zone of the West Siberia

\begin{tabular}{|l|c|c|c|c|c|c|c|c|c|c|c|}
\hline \multirow{2}{*}{ Species } & SB-1 & \multicolumn{3}{|c|}{ SB-2 } & \multicolumn{2}{|c|}{ SA-1 } & \multicolumn{2}{|c|}{ SA-2 } & \multicolumn{2}{c|}{ SA-3 } & Recent \\
\cline { 2 - 15 } & $\mathbf{1 *}$ & $\mathbf{2}$ & $\mathbf{3}$ & $\mathbf{4}$ & $\mathbf{5}$ & $\mathbf{6}$ & $\mathbf{7}$ & $\mathbf{8}$ & $\mathbf{9}$ & $\mathbf{1 0}$ & \\
\hline Castor fiber & & & & & & & & & & & \\
\hline Lepus timidus & 377 & 1086 & 167 & 901 & & 53 & 81 & 115 & 25 & 995 & + \\
\hline Canis lupus & & 5 & 7 & 4 & & 3 & & & & 2 & + \\
\hline Vulpes lagopus & 69 & 175 & 10 & 200 & & 37 & 2 & 13 & 4 & 245 & + \\
\hline Vulpes vulpes & 3 & 9 & 17 & 1 & & & & & & 7 & + \\
\hline Ursus arctos & 15 & 13 & 5 & & & & & & & 1 & + \\
\hline Lutra lutra & & & & & & & & & & & \\
\hline Gulo gulo & & 6 & 2 & & & & & & 1 & 4 & + \\
\hline Martes zibellina & 15 & 8 & & & & & & 2 & & & \\
\hline Mustela erminea & 4 & 12 & & & & 2 & & & & 9 & + \\
\hline M. nivalis & 2 & 9 & & & & & & & & 5 & + \\
\hline Alces alces & 3 & 6 & 3 & 8 & & & 1 & & 1 & 22 & + \\
\hline Rangifer tarandus & 269 & 856 & 1421 & 673 & 82 & 246 & 61 & 8 & 145 & 1755 & + \\
\hline Total & 757 & 2185 & 1632 & 1787 & 82 & 341 & 145 & 138 & 176 & 3045 & + \\
\hline
\end{tabular}

*1 - Zveroboy (layer 4); 2 - Zveroboy (layer 3); 3 - Yangana-Pe-2 (layer 3); 4 - Yangana-Pe-3 (-43-73 cm); 5 - Yangana-Pe-2 (layer 2); 6 - Yangana-Pe-4; 7 - Yangana-Pe-3 (-23-43 cm); 8 - Yangana-Pe-5; 9 - Yangana-Pe-3 (0-23 cm); 10 - Zveroboy (layer 1).

Table 3. Species composition and abundance of mammal bone remains in the localities of the central and southern part of forest-tundra zone of the West Siberia

\begin{tabular}{|c|c|c|c|c|c|c|c|c|c|c|c|}
\hline \multirow{3}{*}{ Species } & \multirow{3}{*}{$\begin{array}{l}\text { SB-1 } \\
11 *\end{array}$} & \multirow{2}{*}{\multicolumn{2}{|c|}{ SA-1 }} & \multirow{2}{*}{\multicolumn{2}{|c|}{ SA-2 }} & \multicolumn{5}{|c|}{$\mathrm{SA}-3$} & \multirow{3}{*}{ Recent } \\
\hline & & & & & & \multicolumn{4}{|c|}{ XII-XVII century } & \multirow{2}{*}{$\begin{array}{c}\begin{array}{c}\text { XVIII- } \\
\text { XIX } \\
\text { cent. }\end{array} \\
\mathbf{2 0} \\
\end{array}$} & \\
\hline & & 12 & 13 & 14 & 15 & 16 & 17 & 18 & 19 & & \\
\hline Castor fiber & 1 & 655 & 4 & 51 & 34 & 360 & 245 & 22 & 10 & & + \\
\hline Lepus timidus & & 1075 & 6 & 88 & 457 & 11660 & 26223 & 1406 & 3767 & 22 & + \\
\hline Canis lupus & & 4 & 1 & & & 27 & 204 & 22 & 5 & 6 & + \\
\hline Vulpes lagopus & & 246 & 5 & 14 & 316 & 9449 & 12620 & 1030 & 119 & 13 & + \\
\hline Vulpes vulpes & & 124 & 1 & 21 & 5 & 349 & 577 & 19 & 10 & & + \\
\hline Ursus arctos & & 2 & & 2 & & & 5 & 1 & 24 & & + \\
\hline Lutra lutra & & 1 & & & & 1 & 6 & & & & + \\
\hline Gulo gulo & & 2 & & & & 149 & 398 & 47 & 27 & 3 & + \\
\hline Martes zibellina & & 78 & & 1 & 33 & 1022 & 515 & 6 & 3 & & \\
\hline Mustela erminea & & 13 & & 7 & & 168 & 320 & 11 & 25 & & + \\
\hline M. nivalis & & & & & & & & & & & + \\
\hline Alces alces & 13 & 37 & 5 & 1 & 1 & 16 & 47 & 24 & 177 & 30 & + \\
\hline Rangifer tarandus & 105 & 9104 & 415 & 90 & 880 & 6760 & 12389 & 7111 & 2768 & 2566 & + \\
\hline Total & 119 & 11341 & 437 & 275 & 1726 & 29961 & 53549 & 9699 & 6935 & 2640 & \\
\hline
\end{tabular}

*11 — Gorny Samotnel-1; 12 - Ust'-Poluy; 13 - Salekhard-1; 14 - Zeleny Yar; 15 - Zelenaya gorka; 16 - Nadymskiy gorodok (layers XV-XVI centuries.); 17 - Nadymsky gorodok (layers XVI-XVIII centuries); 18 - Poluysky mysovoy gorodok; 19 - Mangazeya; 20 - Obdorsk. 


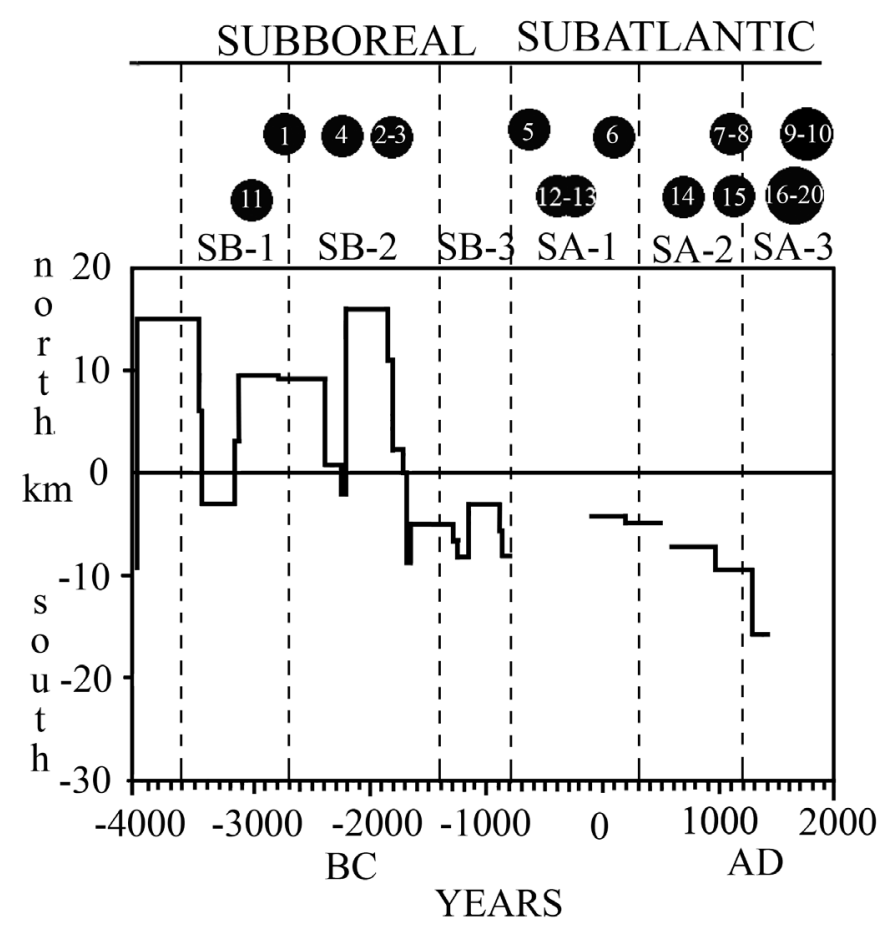

Fig. 2. Changes of the northern boundary of the coniferous trees distribution in the Yamal Peninsula (according to Khantemirov \& Shiyatov, 1999) and chronology of the studied localities. Locality labels (1-20) are the same as in Tables 2 and 3.

mains from the archeological sites characterize human hunting activity. Indigenous peoples mostly subsisted on hunting and fishing (Vizgalov et al., 2013). Hunting was non-selective, therefore, it may be assumed that the species composition and species ratio of the hunting samples in general reflect those found in the natural environment. Differences observed at the sites dated to different time periods reflect age-long changes in the animal numbers. The only exception is the reindeer because some of its records can represent a domestic form. For the Russian population, hunting was of secondary importance and was selective (Vizgalov et al., 2013), therefore, the remains from these sites allow us to identify only faunal composition.

The earliest fauna comes from the lowest layer 4 of the Zveroboy. It is dated to the beginning of the Subboreal period (Tab. 1). The remains from the lower layers of the Yangana-Pe-2 and Yangana-Pe-3 sites, and the remains from the lower part of layer 3 from the Zveroboy cave characterize the end of the Subboreal period (Tab. 1). The fauna of the beginning of the Subatlantic period may be characterized on the basis of the remains from the Ust-Poluy and Salekhard 1 archeological sites (Tab. 1 ), as well as from layer 2 of Yangana-Pe-2 and the upper part of layer 3 of the Zveroboy. The remains from other sites belong to large mammals of the second half of the Subatlantic period (Tab. 1).

It is pertinent to mention the characteristic features of the faunal composition of some archeological sites. Several archeological sites did not yield any remains of the wolf (Canis lupus), fox ( $V$. vulpes), brown bear
(Ursus arctos), weasel (Mustela erminea), and wolverine (Gulo gulo). These animals were most probably present in the natural assemblages (Tabs. 2, 3) but were not found due to small sample size. In addition, the least weasel $(M$. nivalis L., 1766) is missing in the species lists because people did not hunt it.

The analysis of the obtained data indicates that the revealed fauna includes species from different faunal complexes. Thus, the polar fox ( $V$. lagopus $)$ is a representative of the tundra assemblage; the sable $(M$. zibellina) and moose (Alces alces) are from the taiga mammal assemblage; the reindeer ( $R$. tarandus) comes from the tundra and taiga assemblages; azonal species, such as the beaver (Castor fiber L., 1758) and otter (Lutra lutra); intrazonal species, such as the mountain hare (Lepus timidus L., 1758), wolf (C. lupus), red fox (Vulpes vulpes), weasel (M. erminea), least weasel ( $M$. nivalis), wolverine (G. gulo), and brown bear (U. arctos). The intrazonal species and the reindeer (Tabs. 2, 3 ) are most abundant in the large mammal fauna of the forest-tundra zone.

The fauna of the sites located in the north of the forest-tundra zone and the sites in its central and southern parts are characterized by different species composition. The sites in the northern part of the forest-tundra do not yield any remains of the beaver or otter (entering the forest-tundra zone through large rivers) dated to the period under study (Kirikov, 1960; Aristov \& Baryshnikov, 2001).

In the northern part of the region sable remains were found only in three localities (Tab. 2). The earliest sable 
remains were found in the localities of the Subboreal period (SB-1 and SB-2) (Tab. 2). In two localities of the early Subatlantic period (SA-1) sable remains are absent (Tab. 2). One of the sites (Yangana-Pe-3) yielded only reindeer remains (Tab. 2). Therefore, we can characterize the fauna of the early Subatlantic period only based on the assemblage of Yangana-Pe-4 (Tab. 2). Among several localities of earlier and later periods sable remains were found only in two sites (Tab. 2). Thus, we infer the presence of sable in the early Subatlantic period.

The latest find of this species comes from the Yangan-Pe-5 which dates to mid Subatlantic period (SA-2). In later deposits of Zveroboy this species was not found (Tab. 2). At the same time, a noticeable number of sable remains are documented by the assemblage in the earlier deposits of the Zveroboy (Tab. 2). In addition, sable remains were found at the Bukhta Nakhodka site (Vizgalov et al., 2013). This site is located farther north of the modern boundary of the forest-tundra zone (Fig. 1). The remains from this site are dated to the 12th through the beginning of the 14th centuries (boundary between SA-2 and SA-3) (Vizgalov et al., 2013). Thus, relying on this data we assume that the sable survived in the northern forest-tundra zone until the beginning of SA-3.

In the central and southern parts of the forest-tundra zone, based on the 18th-19th century record from the Obdorsk sites, sable or beaver remains were not found (Tab. 3). At the same time, in the sites of earlier periods, with comparable sample size to Obdorsk, the remains of these species are persistently present. Furthermore, the Obdorsk sites lack remains of several species (red fox, bears and ermine) that are found in nearly all localities. This is why we cannot draw any conclusions about the beaver and sable distribution in the forest-tundra zone during the 18th-20th centuries. The remains of all other species are present in faunas of all time periods of the Late Holocene (Tabs. 2, 3).

The obtained data indicates the predominance of the mountain hare, reindeer, and polar fox (Tabs. 2, 3). Remains of these species prevail both at the localities with zoogenic deposits and at the archeological sites.
The ratio analysis of the reindeer and moose remains shows consistently higher share of the reindeer in comparison with that of the moose in all localities (Tabs. 2, 3 ). The share of moose remains in most localities does not exceed $1 \%$. Two sites do not fit the overall picture. In the Gorny Samotnel-1 the share of moose remains is $11 \%$. The sample size at this locality is small (Tab. 3) with 13 moose bones versus 100 reindeer bones. At the same time localities with similar number of reindeer bones (Yangana-Pe-3 and Zeleny Yar) yielded only one or two moose bones (Tabs. 2, 3). Therefore, we believe that a higher share of moose remains in the Gorny Samotnel-1 can reflect a higher number of this species in nature during early Subboreal period in the central part of the region. Another dissimilar site, the Mangazeya, shows the share of moose remains of $6 \%$, probably reflecting a higher relative share of the moose in the eastern part of the forest-tundra zone in comparison with its western part.

The ratio analysis of the carnivores group demonstrates that the bones of the polar fox dominate in all localities (Tab. 4). In Zveroboy (layer 1), dated to earliest Subborel period (SB-1), the share of sable is noticeably higher in comparison with other localities of northern part of the region (Tab. 4). At the Ust-Poluy site, dated to the early Subatlantic period, shares of the red fox and sable are noticeably higher in comparison with other localities of the central part of the region (Tab. 4). The higher representation of these species cannot be explained as a specific geographic feature of this site, because the adjacent site of Zelenaya gorka (Fig. 1) shows low shares of the red fox and sable, similar to other sites.

\section{Discussion}

The species composition of large mammals in the center and in the south of the forest-tundra zone remained constant till the beginning of the 18th century (Tabs. 2, 3). The data from archeological sites do not allow to draw a definite conclusion about the beaver and sable range in the central part of the forest-tundra zone during

Table 4. Ratio (\%) of carnivore remains in the localities of the forest-tundra zone of the West Siberia

\begin{tabular}{|l|c|c|c|c|c|c|c|c|c|c|c|}
\hline \multirow{3}{*}{ Species } & \multicolumn{4}{|c|}{ northern part } & \multicolumn{6}{c|}{ central and southern part } \\
\cline { 2 - 17 } & SB-1 & \multicolumn{2}{|c|}{ SB-2 } & SA-1 & SA-3 & SA-1 & SA-2 & \multicolumn{4}{|c|}{ SA-3 } \\
\cline { 2 - 16 } & $\mathbf{1}^{*}$ & $\mathbf{2}$ & $\mathbf{4}$ & $\mathbf{6}$ & $\mathbf{1 0}$ & $\mathbf{1 2}$ & $\mathbf{1 5}$ & $\mathbf{1 6}$ & $\mathbf{1 7}$ & $\mathbf{1 8}$ & $\mathbf{1 9}$ \\
\hline Canis lupus & 0 & 2 & 2 & 7 & 1 & 1 & 0 & 0,2 & 1 & 2 & 2 \\
\hline Vulpes lagopus & 65 & 77 & 98 & 88 & 91 & 52 & 89 & 85 & 86 & 91 & 56 \\
\hline Vulpes vulpes & 3 & 4 & 0 & 0 & 3 & 26 & 1 & 3 & 4 & 2 & 5 \\
\hline Ursus arctos & 14 & 6 & 0 & 0 & 0,4 & 0,4 & 0 & 0 & 0 & 0,1 & 11 \\
\hline Lutra lutra & 0 & 0 & 0 & 0 & 0 & 0,2 & 0 & 0 & 0 & 0 & 0 \\
\hline Gulo gulo & 0 & 3 & 0 & 0 & 1 & 0,4 & 0 & 1 & 3 & 4 & 13 \\
\hline Martes zibellina & 14 & 4 & 0 & 0 & 0 & 17 & 9 & 9 & 4 & 1 & 1 \\
\hline Mustela erminea & 4 & 5 & 0 & 5 & 3 & 3 & 0 & 2 & 2 & 1 & 12 \\
\hline Total bone & 106 & 228 & 41 & 205 & 42 & 268 & 470 & 45 & 354 & 11165 & 14645 \\
\hline
\end{tabular}

*For number labels of localities see Tables 2 and 3. 
the 18th-20th centuries. According to the literature, the extreme northern limit of the sable range in the Urals in the 18th-19th centuries reached the Voikar River, i.e. about 150-200 km to the south from Salekhard (Kirikov, 1960). This is confirmed by the 18 th-19th centuries materials from the Ust-Voikar site (Bachura \& Nekrasov, 2010). According to Skalon (1951), beavers lived in the Obdorsk (currently Salekhard) area till the 16th century. Materials from the site of Poluysky mysovoy gorodok show that the beaver lived in the Obdorsk area at least till the end of the 17th century. In Mangazeya district people caught beavers almost every year until the end of the 17 th century (Kirikov, 1960; 1966). Thus, based on data from archeological sites and literature sources we believe that by the mid 18th century the sable and beaver had been hunted to extinction there. Today these species are also absent from the forest-tundra zone (Gashev, 1996; Monakhov, 1995).

The dynamics of the species composition in the northern part of the forest-tundra zone is somewhat different. The sable inhabited this area throughout the Subboreal period (Tab. 2). Materials from only one locality do not allow a definite conclusion about the sable range in the northern part of the region in the early Subatlantic period. Because sable remains are present in sites of earlier and later periods we infer its presence at the beginning of the Subatlantic period. In the mid Subatlantic its range covered the southern parts of the tundra zone. Later, at the beginning of SA-3, its range shifted to the south. At that time in the Yamal Peninsula, the northern boundary of the forest vegetation was shifting to the south (Fig. 2; Khantemirov \& Shiyatov, 1999). This, as well as overhunting of the fur-bearing animals by the indigenous peoples, might have led to the sable range contraction.

Throughout the entire Late Holocene mountain hare, reindeer, and polar fox were the most widespread large mammals in the West Siberian forest-tundra zone.

In the Late Holocene the relative numbers of the reindeer in the forest-tundra zone remained persistently high, while the numbers of the moose stayed low. In the early Subboreal time the moose abundance in the central part of the forest-tundra zone was higher than during the Subatlantic period. In the early Subboreal time the northern boundary of light forests on the Yamal Peninsula was some $20-30 \mathrm{~km}$ further north than during the Subatlantic period (Fig. 2; Khantemirov \& Shiyatov, 1999). It is probable that it was this forest expansion in the early Subboreal period that resulted in higher moose numbers compared with a later time period. The moose was relatively more abundant in the eastern part of the West Siberian forest-tundra zone than in its western part.

The available data demonstrate that the polar fox numbers in the West Siberian forest-tundra zone remained persistently high throughout the whole period under study. In the northern part of the region in the early Subboreal time the relative numbers of sable were higher than at later time. In the central part of the region the sites dated to early Subatlantic time document higher relative numbers of the sable and red fox than at later time. The palynological data and the data on the northern border of forest vegetation (Fig. 2) indicate a warmer climate at the early Subatlantic time as compared to the later period (Khantemirov \& Shiyatov, 1999; Panova \& Yankovskaya, 2008). At the same time, the forest boundary at the beginning of the Subboreal time on the Yamal Pennsula was more to the south than in the middle of this period (Fig. 2; Khantemirov \& Shiyatov, 1999). Consequently, in the mid Subboreal time the climate was warmer than at its beginning. But the relative number of sable shows the opposite trend. Thus, the dynamics of the red fox and sable numbers during the Holocene in the forest-tundra zone does not have an obvious connection with the dynamics of climate.

\section{Conclusions}

Throughout the Late Holocene the species composition of West Siberian large mammals was nearly constant and similar to the present day fauna. The fauna was dominated by azonal species. The species composition of the southern part of forest-tundra zone differed from the northern part in the presence of the beaver and otter. Minor changes in the faunal composition took place only in the northern part of this area at the end of the Subatlantic period. This involved the dynamics of the northern boundary of the sable range. It was due to the shift of the northern forest boundary and increased sable fur trade. People completely exterminated beavers and sables in the region by the mid 18 th century.

The mountain hare, polar fox, and reindeer were the most numerous species in the large mammal fauna of the West Siberian forest-tundra zone, similar to the present day situation. The numbers of these species were persistently high throughout the entire Late Holocene. The abundance of other species during the period was lower. The record of the Late Holocene evidences a noticeable fluctuations in numbers of the red fox, sable, and moose. The modern mammal species composition of the forest-tundra zone was formed by the interplay of climate change and the human commercial activity.

ACKNOWLEDGMENTS. The specimens were collected under the State Contract of the Institute of Plant and Animal Ecology, UB RAS. Data analysis was supported by the Russian Foundation for Basic Research, project no. 18-04-00982a.

\section{References}

Aristov A.A. \& Baryshnikov G.F. 2001. [The mammals of Russia and adjacent territories. Carnivores and Pinnipeds]. Saint Petersburg: Zoological Institute RAS. 560 p. [In Russian].

Bachura O.P., Kosintsev P.A., Gimranov D.O., Korona O.M., Nekrasov A.E. \& Panteleev A.P. 2017. [Ust-Polui: economic activities of the population and the natural environment] // Archeology of the Arctic. Ust-Poluy: materials and research. Issue. 4. Ekaterinburg: Izdatel'stvo Delovay pressa. P.81-99. [In Russian]. 
Gashev S.N. 1996. [Theriofauna of the Tyumen region and its protection] // The condition of the theriofauna in Russia and the near abroad. Moscow. P.83-90. [In Russian].

Golovachev I.B. \& Smirnov N.G. 2009 The Late Pleistocene and Holocene rodents of the Pre-Urals subarctic // Quaternary International. Vol.201. P.37-42.

Kadebskaya O.I. \& Kosintsev P.A. 2012. [Karst phenomena of Yanganape and Nyavape Rivers (Polar Urals)] // Problems of Regional Ecology. No.6. P.42-48. [In Russian].

Khantemirov R.M. \& Shiyatov S.G. 1999. [Radiocarbon and dendrochrological dating of subfossil wood from the Yamal Peninsula and usage of those in studies of forest-tundra ecosystems dynamics] // Biota of the Pre-Urals Subarctic in Late Pleistocene and Holocene. Ekaterinburg: Izdatel'stvo Ekaterinburg. P.3-22. [In Russian with English summary].

Khotinsky N.A., Aleshinskaya Z.V., Guman M.A., Klimanov V.A. \& Cherkinskiy A.E. 1991. [New scheme of the periodization of landscape and climatic changes in the Holocene] // Izvestiya AN SSSR. Seriya geograficheskaya (Bull. of the Academy of Sci. of the USSR. Geographic series). No.3. P.30-42. [In Russian].

Kirikov S.V. 1960. [Changes in the animal world in the natural zones of the USSR (XIII - XIX centuries): Forest zone and forest-tundra]. Moscow: Academy of Sciences of the USSR. 156 p. [In Russian].

Kirikov S.V. 1966. [The game animals, the natural environment and man]. Moscow: Nauka. 348 p. [In Russian].

Kosintsev P.A. 2009. [The burial wolf's den in the Polar Urals] // The Yenisei province. Krasnoyarsk: Krasnoyarsk Regional Museum of Local Lore. Issue 4. P.108-118. [In Russian].

Kosintsev P.A. \& Lobanova T.V. 2003. [Late Holocene megamammals of West Siberia forest-tundra] // Quaternary paleozoology in the Urals. Ekaterinburg: Ural State University. P.171-176. [In Russian].

Kosintsev P.A. \& Lobanova T.V. 2006. [Large mammals of the West Siberian forest-tundra zone over the Late Holocene] // Dynamics of the recent ecosystems over the Holocene. Proceedings of the Russian Scientific conference. Moscow, Russia, February 2-3, 2006. Moscow: KMK Scientific Press Ltd. P.113-116. [In Russian].
Monakhov V.G. 1995. [Sable of the Urals, Priobye and Yenisei Siberia]. Ekaterinburg: Bank kul'turnoy informatcii. 154 p. [In Russian].

Nomokonova N.Yu., Lozei R.J., Tupahin O.S. \& Tupahin D.S. 2017. [Subsistence patterns of population of the Lower Ob river basin during the Eneolithic (based on faunal remains of the settlement of Gorniy Samotnel-1)] // Bulletin of archeology, anthropology and ethnography. Vol.36. No.1. P.143-149. [In Russian with English summary].

Panova N.K. \& Yankovskaya V. 2008. [Results of spore-pollen analysis of the Ust-Poluy monument and sediments in the vicinity of Salekhard] // Scientific Bulletin of the Yamal-Nenets Autonomous District. Vol.9(61). P.55-64. [In Russian].

Ponomarev D.V. 2001. [Megamammals of the European NorthEast in Late Pleistocene and Holocene]. Syktyvkar: Komi Scientific Centre. 48 p. [In Russian with English summary].

Reimer P.J., Bard E., Bayliss A., Beck J.W., Blackwell P.G., Bronk Ramsey C., Buck C.E., Cheng H., Edwards R.L., Friedrich M., Grootes P.M., Guilderson T.P., Haflidason H., Hajdas I., Hatte C., Heaton T.J., Hoffmann D.L., Hogg A.G., Hughen K.A., Kaiser K.F., Kromer B., Manning S.W., Niu M., Reimer R.W., Richards D.A., Scott E.M., Southon J.R., Staff R.A., Turney C.S.M. \& van der Plicht J., 2013. IntCal13 and Marine13 radiocarbon age calibration curves $0-50000$ years cal BP // Radiocarbon. Vol.55. No.4. P.1869-1887.

Skalon V.N. 1951. [River beavers of northern Asia]. Moscow: Moscow Society of Naturalists, MOIP. 208 p. [In Russian].

Velichko A.A., Andreev A.A. \& Klimanov V.A. 1994. [Dynamics of vegetation and climate in tundra and forest zones of Northern Eurasia in Late Glacial and Holocene] // Short-period and sharp landscape-climatic changes over the last 15000 years. Moscow: Institute of Geography RAS. P.4-60. [In Russian].

Vizgalov G.P., Kardash O.V., Kosintsev P.A. \& Lobanova T.V. 2013. [Historical ecology of the population of the north of Western Siberia]. Nefteyugansk: Institute of the Archaeology of the North, Ekaterinburg: AMB. 374 p. [In Russian]. 